\title{
10 Great Places to Go for Free Help!
}

Julie A Meek, PhD, RN, CNS

Clinical Associate Professor

Coordinator of DNP Program

Indiana University School of Nursing

This is the author's manuscript of the article published in final edited form as:

Meek, J. A. (2015). 10 great places to go for free help!. Clinical Nurse Specialist, 29(1), 19-21.

http://dx.doi.org/10.1097/NUR.0000000000000091

\section{Key words: Entrepreneurship; resources; business}

Feel like you're working so hard in your business, that you don't have time to work on your business? It's challenging for sure, to take the time to reflect upon what's going well and yet what challenges currently face you and your business. Yet as Jay Goltz shared in his New York Times small business blog, it's important to take a breather once in a while to learn more and to get the kind of help and advice you need to take your business to the next level. ${ }^{1}$

The great news is that there are a plethora of free places you can go. ${ }^{2-4}$ Here are 10 types of places you can go to learn more about your industry and to find the business help and advice you need:

1) Government websites. The 2010 passage of the Affordable Care Act, while creating a complete sea change for healthcare, also created new niche markets for entrepreneurs ready to capitalize on opportunity. Staying current with federal/state legislation and your own state's nursing association is essential if your business is connected in any way with the government or government funding. Particularly important sites include:

- U.S. Department of Health \& Human Services \& Centers for Medicare \& Medicaid (CMS) outlines all of the latest changes related to the passage of the Affordable Care Act in 2010. Link for HHS: http://www.hhs.gov/healthcare/rights/ \& link for CMS: www.cms.gov

- Agency for Healthcare Research \& Quality (AHRQ) is a government agency whose purpose is to advance quality and safety excellence in healthcare. This site is an excellent resource for latest 
evidence, data, and research recommendations across a variety of healthcare topics. Link:

www.ahrq.gov

- Institute of Medicine (IOM) is an independent, non-profit agency that works outside of government to ask and answer pressing questions about health and health care. The site is home to some of the most important reports shaping our healthcare system today. Link: www.iom.edu

- American Nurses Association with its affiliated State Nurses' Associations is the collective organization representing the interests of our nation's 3.1 million registered nurses. Becoming an active member of your state's organization is a key place where you can find contacts and important networks for your business. Link: http://www.nursingworld.org/snas.aspx

2) Small Business Administration. The SBA was formed in 1953 to help entrepreneurs form and successfully grow their small businesses. Free resources include assistance with writing business plans, loans, loan guarantees, and an index of help topics for starting and managing your business. Link: $\underline{w w w . s b a . g o v}$

\section{3) Professional healthcare specialty organizations.}

- Institute for Healthcare Improvement website (IHI) provides all things "Triple Aim". The website is full of white papers, learning modules, blogs, reading lists and more. Link: www.ihi.org

- American College of Healthcare Executives (ACHE) is a great source of information for those desiring to lead and/or serve healthcare leaders. Link: www.ache.org

- American Organization of Nurse Executives (AONE) provides similar learning resources for nursing leaders. Link: $\underline{w w w . a o n e . o r g}$

- National Association of Clinical Nurse Specialists (NACNS) is the professional organization for clinical nurse specialists and is listed here as an example of a specialty organization with its own set of learning resources and latest trend information. Each nursing specialty has a similar organization. Link: $\underline{w w w . n a c n s . o r g}$

4) Online entrepreneur forums. Entrepreneurs are known for needing a like-minded community with whom they can share the trials and tribulations of starting and running a business. There's a lot of great help out there in 
these forums, so here are a few of the best entrepreneur forums where you can pose questions, share your woes and triumphs, and receive helpful information.

- Entrepreneur.com is great as a general forum, but you can find your own industry-based group as well. Link: http://econnect.entrepreneur.com/browse_groups.php

- $\quad$ Startup Nation is especially good if you thinking about starting up a business. Link: http://www.startupnation.com/community/

- Intuit Community also has a general business section plus specific industry forums plus a helpful way to sort advice based on your question/reasons for searching the forum. Link: http://community.intuit.com/start_and_grow

- Young Entrepreneur Forum is great for connecting with entrepreneurs from all over the world. The site offers paid membership which gives users access to special functionality including events, private messaging, webinars, etc. Link: http://www.youngentrepreneur.com/forum/

5) LinkedIn groups. Another pasture of information for your brain are Linkedln groups. There are general and highly specialized groups, so use search terms to find the group you need and sign up. Link: https: www.linkedin.com/groups. A few of the general entrepreneurial groups to search for on LinkedIn are:

- On Startups: Find insightful articles from entrepreneurs.

- $\quad$ Sales Best Practices: This site provides a great way to hone your sales skills.

- $\quad$ Succeed: Small Business Network, Powered by Staples: Entrepreneurs with different sized businesses discuss various topics.

6) Blogs. Finding a blog that speaks to you in ways that are helpful can take some searching, but when you find one that delivers real value, add it to your favorites list and RSS feed. Some top picks that could prove useful:

- Search Engine Land: If search engine marketing is central to your business, this site includes news and analysis regarding search-engine marketing in addition to general entrepreneur content. Link: http://searchengineland.com/

- Small Business Trends: This blog highlights small companies and offers lots of how-to advice. Link: http://smallbiztrends.com/ 
- Social Media Examiner: This blog covers lots of advice on the use of social media for marketing. Link: http://www.socialmediaexaminer.com/

7) MOOCs. Need to learn a skill and can't afford the time, much less the tuition? The list of universities offering MOOCs (Massive Open Online Courses) is rapidly expanding and each MOOC offers hundreds of topics related to running a small business, e.g., accounting basics, marketing, intellectual property protection, etc. Some well-known MOOC sites include:

- Coursera is well known and has hundreds of courses. Link: http://www.coursera.com/

- Stanford Online is a great example of a private university-based MOOC. Link: http://www.stanfordonline.edu/

- MOOC List provides an ever-growing list of all MOOC courses across platforms. Link: http://www.mooclist.com/

8) Webinars. Everyone learns differently. If you like videos and interacting with your teachers, look for online webinars, both live and recorded, as valuable teaching tools. Again, some of these will be free, but the real value will be found in the ones that charge even a nominal fee.

- Google Hangouts: Sign up for a free Gmail account and you can search for whatever you want to learn more about with the Hangout function available on Google+. Search for a topic you're interested in and join a Hangout on Air or view the recorded Hangout later on YouTube. Link: http://www.google.com/

- BizLaunch: This site offers free webinars on a variety of entrepreneur-focused topics. Link: http://www.bizlaunch.com/small-business-webinars/

9) Videos. With the arrival of streaming video on virtually every mobile device, you can take advantage of "wait times" as precious moments to learn from the vast array of video distribution channels.

- YouTube: Yes, there are cute pet videos, but YouTube also offers entrepreneurs some great resources with channels like Small Business Television Network and Small Business Building. Link: https://www.youtube.com/channels?q=small+business 
- Justin.tv: With more live channels than you'll ever be able to watch, you're sure to search for and find useful business advice. Link: http://www.justin.tv/

- Videolla: Gaining viewership, this site offers great advice, such as "How to pitch to investors in under two minutes" and "A formula for business success". Link: $\underline{\text { http://videolla.com/shows }}$

10) Twitter chats. Join a scheduled Twitter chat and be amazed at how much you can learn. Chats can be joined in real time or if you're on the run, you can scroll back through tweets later. Also learn all about how to market your business on Twitter by going to the Business section. Link: https://business.twitter.com/twitter-basics

- \#SmallBizChat: If you are interested in a wide range of small business owner topics, tune in each Wednesday at 8 p.m. ET.

- \#BlogChat: This is a well-attended chat with great lineup of business experts. This one is on Sundays at 9 p.m. ET.

- $\quad$ \#B2BChat: Network and learn from business owners on Thursdays at 8 p.m. ET.

Just knowing about all of these free and widely available resources can be overwhelming. So like anything else in your business, pare down the options you're interested in, then schedule a few resources a week to explore. Once you have broadly sampled, you can narrow down your list to the resources you find are most helpful. Chances are the free gains in your knowledge and skills as an entrepreneur will make the time well spent. 
References:

1) Goltz, J. (April 21, 2011). A plan for working on (not in) the business. New York Times. Retrieved Sept 10, 2014 from http://boss.blogs.nytimes.com/2011/04/21/a-plan-for-working-on-not-in-thebusiness/? php=true\& type=blogs\& $r=0$.

2) Demers, J. (2014). 21 Resources to make you a better entrepreneur. Entrepreneur. Retrieved Aug 31, 2014 from http://www.entrepreneur.com/article/236355

3) Lang, B. (2014). 10 Forums every young entrepreneur should belong to. Business Insider. Retrieved Aug 31 , 2014 from http://www.businessinsider.com/10-forums-every-young-entrepreneur-should-belong-to-2012-10

4) Canty, A. (2010). Great 8: Top entrepreneur forums on the Web. Grasshopper. Retrieved Aug 31, 2014 from http://grasshopper.com/blog/great-8-top-entrepreneur-forums-on-the-web/ 